\title{
Analysis of the Acceptance and Use of e-Campus Based on the Unified Theory of Acceptance and Use of Technology (UTAUT) Approach at Pelita Bangsa University
}

\author{
Muhtajuddin Danny \\ Informatics Engineering Study Program, Faculty of Engineering, Pelita Bangsa \\ University \\ utat@pelitabangsa.ac.id
}

\begin{abstract}
This study discusses the analysis of the use of academic information systems. This type of research is a descriptive study, using a qualitative approach. The source of the data obtained is primary data which is obtained directly by using questionnaire data. The academic information system at Pelita Bangsa University is a system that provides academic information services. This research, which aims to identify the extent of the academic behavior of the system users, uses Structural Equation Modeling analysis, with the Analysis of Moment Structure as an application for data processing.
\end{abstract}

Keywords: Academic, e-Campus, UTAUT, SEM, AMOS.

\section{Introduction}

Academic information system is a system built to manage academic data so as to make it easy for users in campus academic administration activities online. This is done through information services covering five aspects, namely: information gathering, information processing, information utilization, information dissemination, information maintenance / preservation. Academic information system which aims to support the implementation of this education, provides more effective information services. Designed to process academic data so that the entire process of academic activities can be well managed which is beneficial for management and can be used for decision making for top management in the University environment.

Academic information systems manage all data in an integrated manner so that the data will always be up to date / realtime and always ready for use, and reduce the possibility of data duplication because of the intention to use a centralized database system. With automatic email responses, online PMB, class scheduling, online KRS, and online / realtime assessments, all Siakad news or announcements will become a center of information that is always a necessity for the entire campus community.

Academics provide communication media facilities for all users, whether students, lecturers, academic staff, PMB staff, financial staff, even administrators and system leaders to always communicate with each other. The Bekasi Pelita Bangsa academic information system is a Technical Implementation Unit (UPT) that is inseparable from campus activities, which will carry out a quantitative approach with the survey method. The population of Pelita Bangsa University students is 1000 students with an error rate of $5 \%$, so the sample size is 258 students. Samples were taken randomly, using random numbers.

Besides wanting to know the extent to which academic information systems are used by 
students, the researcher also wants to conduct an empirical study, namely examining user behavior in using the system, based on the factors that influence it.

\section{Literature review}

\subsection{Information Technology (IT)}

Information technology (IT) is the use of computers to store, retrieve, transmit, and manipulate data[1] or information. IT is typically used within the context of business operations as opposed to personal or entertainment technologies. IT is considered to be a subset of information and communications technology. An information technology system (IT system) is generally an information system, a communications system or, more specifically speaking, a computer system - including all hardware, software and peripheral equipment - operated by a limited group of users.

Information Technology which is often abbreviated as IT is term from English, namely IT (Information Technology). Information technology includes all matters relating to the manipulation process data and information management. Communication technology includes everything that is relating to the process of delivering or sending information from the sender to the recipient. From the understanding of information technology and communication technology, the two technologies are inseparable equivalent technologies, meaning the two technologies are closely related to each other. Information technology and communication is all forms of activities related to the process manipulation, management, and transfer of information from sender to receiver.

Knowledge of IT helps us to know, use, and maintain IT-related equipment. Besides, we are also have to develop our potential to develop the already existing IT there is now. With IT, the quality of human life in various fields to be increasing.

The needs and lifestyle of the people in the current era have led to developments in various fields, one of which is technology. Changes in learning patterns are needed to make updates to keep up with the dynamics of changing times that are increasingly fast triggered by technological developments. The development of Information Technology (IT) continues to increase along with human needs. With the development and advancement of IT jobs and the problems we face become easier to solve.

\subsection{Structural Equation Model}

SEM (Structural Equation Modeling) is an increasingly popular statistical analysis tool. When viewed from the preparation of the model and how it works, actually SEM is a combination of factor analysis and Regression analysis (Santoso, 2011). Nowadays SEM is no longer just linear and the possibility of SEM expansion will exceed the original Lisrel program. SEM provides a satisfying and very general framework for statistical analysis which includes several traditional multivariate procedures, for example factor analysis, regression analysis, discriminant analysis and canonical correlation as special cases. SEM is often illustrated by a flow chart.

\subsection{AMOS (Analysis of Moment Structure)}

AMOS (Analysis Moment of Structural) is a statistical software for multivariate analysis. Multivariate analyzes that are popular with this software are path analysis and structural equation modeling. AMOS is a statistics software developed by IBM. Amos software is devoted to helping test hypotheses on the relationship between variables. Through this software, we can find out the level of strength of the relationship between variables both latent and manifest variables. How significant is the relationship between variables, and how fit is 
the hypothesis model compared to the real field data.

AMOS is a program designed to complete covariance- based Structural Equation Modeling (SEM) analysis (Ghozali 2005). AMOS is used to analyze data and test a series of hypotheses that have been formulated simultaneously where there are more than one dependent variable that are interrelated and test the feasibility of a model with research data. As a structural equation model, AMOS is more often used in marketing and strategic management research.

\subsection{Unified Theory of Acceptance and Use of Technology (UTAUT)}

The UTAUT aims to explain user intentions to use an IS and subsequent usage behavior. The theory holds that four key constructs (performance expectancy, effort expectancy, social influence, and facilitating conditions) are direct determinants of usage intention and behaviour (Venkatesh et. al., 2003). Gender, age, experience, and voluntariness of use are posited to moderate the impact of the four key constructs on usage intention and behavior (Venkatesh et. al., 2003). The theory was developed through a review and consolidation of the constructs of eight models that earlier research had employed to explain IS usage behaviour (theory of reasoned action, technology acceptance model, motivational model, theory of planned behavior, a combined theory of planned behavior/technology acceptance model, model of PC utilization, innovation diffusion theory, and social cognitive theory). Subsequent validation of UTAUT in a longitudinal study found it to account for $70 \%$ of the variance in usage intention (Venkatesh et. al., 2003).

\section{Study Overview}

\subsection{Erni Dwi Pratiwi (2016), Factors Affecting Intention Use Instagram With The} Theory Of Reasoned Action Using Amos 21

Increasingly widespread social media today would increase public curiosity any social media that exists today, so that various social media more and more devotees, well just try or eventually become active users. Instagram is one of the social media users today are becoming increasingly expanded and increased, with a variety of application purposes instagram use more and more are using. There are several factors that influence a person's intentions and attitudes in using this application. This study used a variable confidence instagram app, satisfaction using instagram app, attitudes in using instagram, instagram and intention using subjective norm. This study is expected to be able to determine what factors that significantly affect the intentions of the users using the application instagram instagram in this. Based on the survey results revealed that the intention to use instagram app is influenced by trust, satisfied with the attitude of the users themselves.

\subsection{Trie Handayani, Sudiana (2012), Analysis Of Application Of Utaut Model (Unified Theory Of Acceptance And Use Of Technology) On Information System User Behavior}

UTAUT is one of the latest technology acceptance models developed by Venkatesh, et al. UTAUT combines the successful features of eight leading technology acceptance theories into one theory. The eight leading theories put together in UTAUT are the theory of reasoned action (TRA), technology acceptance model (TAM), motivational model (MM), theory of planned behavior (TPB), combined TAM and TPB, model of PC utilization (MPTU). , innovation diffusion theory (IDT), and social cognitive theory (SCT). UTAUT has been shown to be more successful than the other eight theories in explaining up to 70 percent of user variants (Venkatesh, et al, 2003). After evaluating the eight models, Venkatesh, et al. found seven constructs that appear to be significant direct determinants of behavioral intention 
or use behavior in one or more of each model.

\subsection{Ridwan Daud Mahande and Jasruddin(National Seminar Proceedings ISBN: 978- 602-6883-93-3), UTAUT Model: An E-Learning Acceptance Evaluation Approach in Postgraduate Programs}

The quality of e-learning implementation will always be related with voluntary user acceptance. To what extent understanding and acceptance of users (lecturers or students) towards the implementation of e-learning is the thing which determines the quality of the success of the implementation e-learning. In accordance with the purpose of the evaluation emphasizes acceptance, then the acceptance model technology is the right evaluation model for used. Unified theory of acceptance and use of technology (UTAUT) is a comprehensive synthesis model acceptance of technology. Evaluation of e-learning acceptance will emphasize the four construct keys of UTAUT, namely: performance expectations, business expectations, social influence, and facility conditions against the intention to accept e-learning. This initial study is expected to become a reference in formulation of policies regarding implementation and continuous development of e-learning on graduate program.

\subsection{Muhammad Zahruddin, Giandari Maulani, Nur Azizah (2018) PermataNet Internet Banking Information System Effectiveness Case study of PT. Bank Permata Tbk using AMOS}

Information technology in the banking world is currently developing rapidly. The dependence of banks on information technology is very high. We always strive to innovate to have an advantage in customer service compared to competitors. PT. Bank Permata Tbk provides internet banking service named PermataNet for the convenience of customer banking transaction activities. The specific objective of this research is to measure the extent to which the effectiveness level of the internet banking information system PermataNet belongs to PT Bank Permata Tbk. Measurement of effectiveness using DeLone and McLean's theory of the Information Success Model. The samples used in this study are customers, Bank Permata employees and employees of Bank Permata partners. The data resulting from distributing questionnaires to system users will be collected as primary data and secondary data used in this study is a literature study to support the theory. For data processing and analysis, the SEM (Structured Equation Modeling) method is used using statistical software AMOS (Analysis Moment of Structural) version 21. The results of this study indicate that the effectiveness level of this internet banking information system is $55.6 \%$ in terms of degrees influence on the same scale.

\section{Research Methods}

This study is an explanatory study of the causal relationship (cause and effect) of the variables observed and examined. The research carried out intends to prove the hypothesis that was built using the Unified Theory of Acceptance and Use Technology (UTAUT) approach, tested using SEM techniques using AMOS 18 tools. With this method an analysis of the factors that influence the utilization of the Pelita Bangsa e-campus system will be carried out.

\subsection{Research Steps}

The stages carried out in this study can be seen in the image below. 


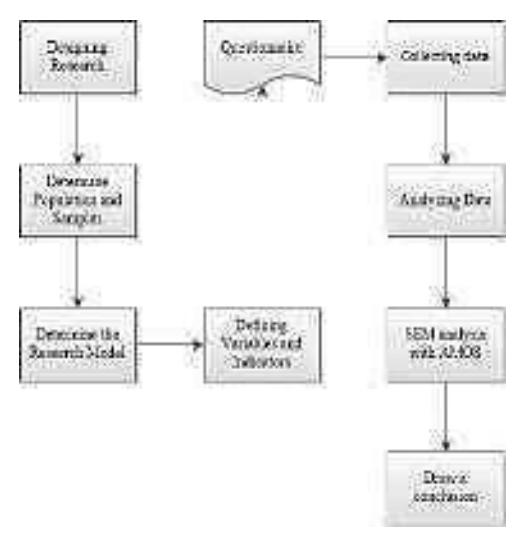

Fig.1. Research Steps

\subsection{Designing Research}

The research conducted is a quantitative study using a survey approach. According to Indrianto and Supomo (1992), "Quantitative approach is a research approach that emphasizes testing theories through measuring research variables with numbers and analyzing data with statistical procedures, this approach aims to test hypotheses through theoretical validation or theory testing. in certain. In the UTAUT model, there are four exogenous variables (independent / independent variables) that have a significant influence on the use of computer technology. The four variables are performance expectancy (the belief that individuals have that their performance will be better when using computer technology), effort expectancy (expectations of ease of use of computer technology), social influence (the level of individual acceptance of the influence of others to use computer technology), and facilitating condition (support facilities / infrastructure owned by individuals to use computer technology).

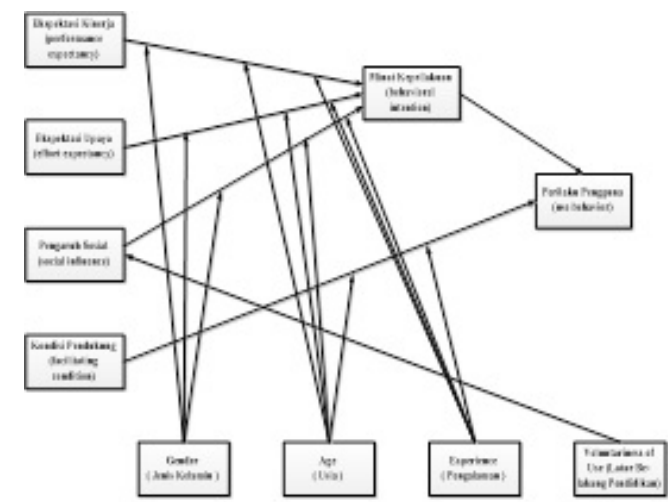

Fig.2. Research Model

\subsection{Make a Questionnaire}

After defining the research variables and indicators, a questionnaire was made to serve as test data for this research hypothesis. Questionnaires are questions made by circumstances ". The survey approach was carried out through distributing questionnaires to samples from a predetermined population. The questionnaire was arranged based on the model used in this 
study, the UTAUT model. Data obtained from the questionnaire were then analyzed using SEM statistical modeling techniques to meet the research objectives.

\subsection{Population and Samples}

Population or Universe is the total number of objects (units or individuals) whose characteristics are to be estimated. These units or individuals are called the unit of analysis. The unit of analysis may be a person, household, farm, company and others in the form normally used in the survey. It may also be a punch card or machine product for various forms of analysis. The unit of analysis is also often called the element of the population.

A study may have more than one unit of analysis, such as households and people, agricultural land and harvested area in hectares. Information (characteristics) collected from the unit of analysis form a statistical data.

The sample is a part of the population whose characteristics are to be investigated, and is considered to be representative of the entire population (the number is less than the total population).

The units to be examined in the sample are called the sample units. This sample unit will be selected from the sample frame. The sample unit may be the same as the unit of analysis, but it may not be. For example, to collect information about people, you can use a complete list from the census and take a sample directly from the list. But it is also possible to choose the household as the unit of analysis. Or we can select the building as the sample unit, and the people who live in the building as the unit of analysis.

\subsection{Research Model}

The model used by researchers in this study adapted the UTAUT model that had been developed previously, with the addition of several constructs as determinants of the variables to be measured in this study. In this study the researcher will measure how much the relationship between the variables and the acceptance of the Academic Information System at Pelita Bangsa University.

\subsection{Collecting data}

Research data collection was carried out by distributing questionnaires directly to all samples conducted within one week. Data from respondents were obtained from questionnaire instruments, using closed questions where respondents could quickly and easily answer questionnaires, so data from questionnaires could be quickly analyzed statistically. The questionnaire is a method of collecting data by giving a set of questions or written statements to the respondent to answer. The questionnaire is a more efficient data collection method if the researcher knows exactly what variables to measure and what is expected from the respondent.

\subsection{SEM analysis with AMOS}

To conduct data analysis using SEM techniques, the tools used in this study are AMOS 18. The steps undertaken to conduct data analysis using SEM techniques are on AMOS tools.

\section{Description of Research Results}

By using independent variables, namely variables that affect or cause changes or the emergence of the dependent variable, the results of the study show that the factors that influence the use of academic information systems are performance expectation. 


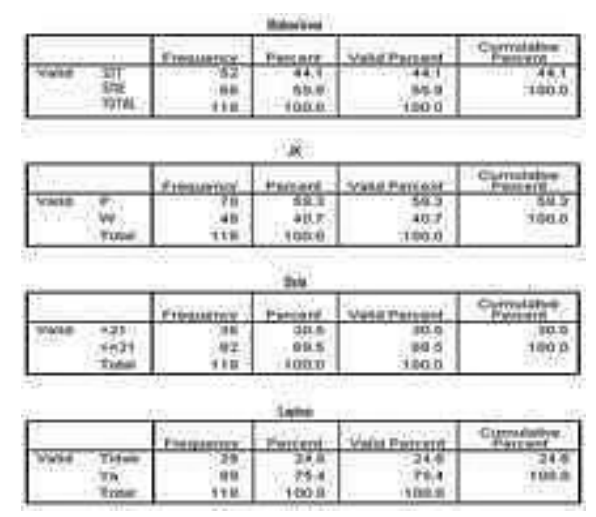

Fig.3. Research Respondent Data

Viewed based on the profile of research respondents, respondents with students of the College of Technology (44.1\%) and the College of Economics (55.9\%), male gender (59.3\%) and Women (40.7), age $<21$ years $(30.5 \%)$ and $>=21$ years $(69.5)$, those who have a Computer / Laptop (75.4\%) and those who do not (24.6\%).

\subsection{Model Conformity Test}

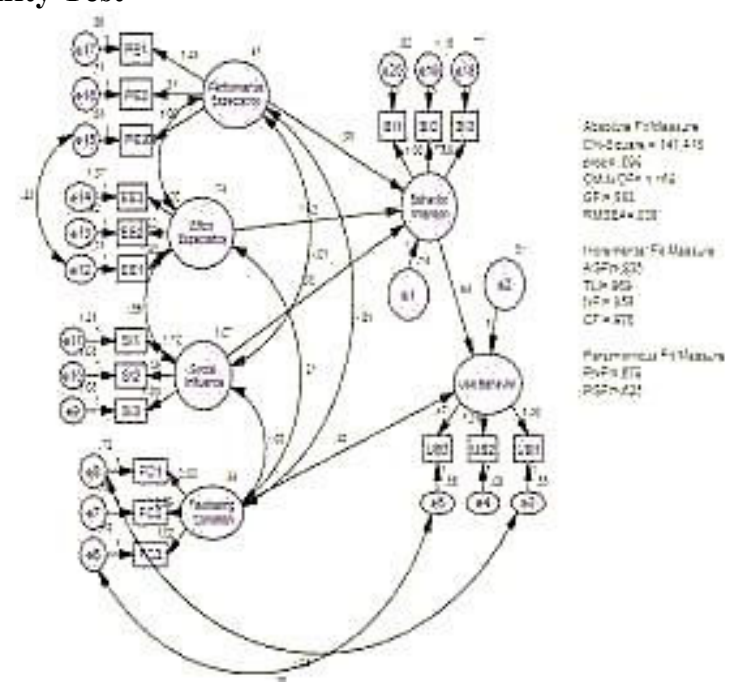

Fig.4. Model Conformity Test

To determine the appropriate criteria or not from a model, it is not only seen from the probability. However, it is also determined by absolute size, to compare the values obtained in the model. 


\subsection{Structural Test Model}

1. Absolute Fit Indices

\begin{tabular}{|c|c|}
\hline \multicolumn{2}{|l|}{ 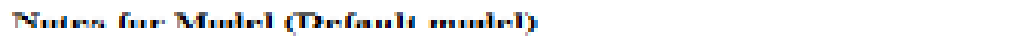 } \\
\hline \multicolumn{2}{|l|}{ Computation of decrees or freedom (betault moded) } \\
\hline Number of distinct sample moment: & 171 \\
\hline 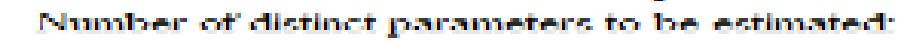 & 50 \\
\hline 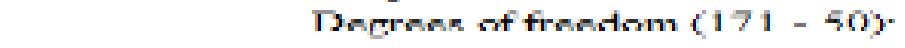 & 121 \\
\hline \multicolumn{2}{|l|}{ 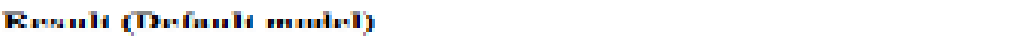 } \\
\hline \\
\hline Chi-м⿻янит: $-141,418$ & \\
\hline 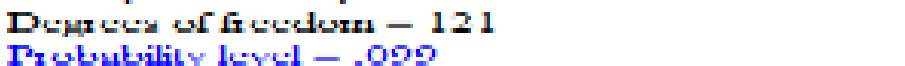 & \\
\hline
\end{tabular}

Fig.5. Computation of degrees of Freedom

Calculate the degree of Freedom (df):

a) The number of independent scores that go into the estimate.

b) the number of parameters used as an intermediate step in the estimation of the parameter itself

2. Number of distinct parameters to be estimated:

a) Amount of Loading Estimates, Practically it can be directly known from the number of one-headed arrows. Namely the construct relationship with the indicator. In this model, there are three relationships for the construct of performance expactancy, three relationships for the construct of effort expectancy, three relationships for the construct of social influence, three relationships for the construct of facilitating conditions, three relationships for the construct of behavioral intentions, three relationships for the construct of behavioral use. Then in total there are $3+3+3+3+3+3=18$ loading estimates.

b) Amount of Error Variance Estimates Namely the number of error variables associated with certain indicators. Because there are 18 loading estimates, there are also 18 error variance estimates.

\subsection{Model Interpretation}

Based on the modification of the model and the results of testing the hypothesis, it can be explained that the model obtained in this study is as follows: 


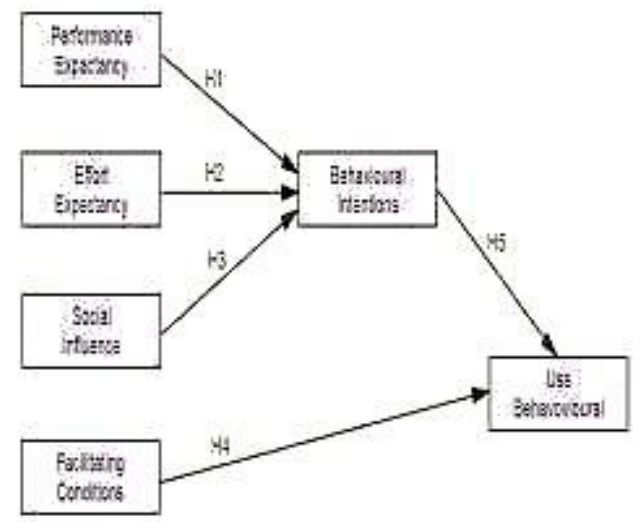

Fig.8. Preliminary Research Model

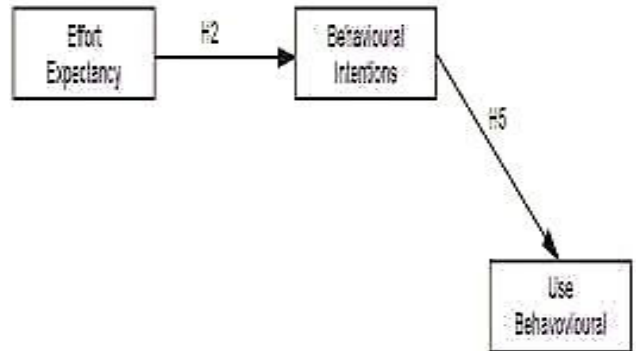

Fig.9. Final Results of Research Model

The image model above shows a comparison of the initial model and the final model of the study, which shows that the effect of using academic information systems for students is:

a) H2: Ease (business expectation) in the use of academic information systems affects the intention to behave in using academic information systems.

b) H5: User behavior (Use Behavovial) in the use of academic information systems is influenced by behavioral intention.

\section{Conclusions}

The conclusions from the results of this study are:

a) Factors that can influence student behavior in using the Universitas Pelita Bangsa academic information system in supporting the learning process are the ease (business expectation) in using the Pelita Bangsa e-campus.

b) The use of academic information systems is strongly influenced by interest or intention.

\section{References}

[1] Adam, Denis,Nelson Ryan and ToddPeter, "Perceived usefullness, ease of use, and usage of Information Technology : Replication”, MIS Quarterly (16:2), 1992, pp. 227-247.

[2] Bacon, L. D., Using Amos for Structural Modelling in Market Research, Lynch, Bacon \& Associates, SPSS Inc., 1997.

[3] Eric Deeson, Harper Collins Publishers, Dictionary of Information Technology, Glasgow, UK,1991. 
[4] Fatmasari, Muhamad Ariandi. (2014). Penerapan Metode Technology Acceptance Model (TAM) Terhadap Penerimaan KRS Online. Jurnal Ilmiah MATRIK, halaman: 135-144.

[5] Ferdinand, A., Structural Equation Modeling Dalam Penelitian Manajemen, Edisi ketiga. Badan Penerbit Universitas Diponegoro, Semarang, 2012.

[6] Ghozali, Imam, Structural Equation Model, Teori Konsep dan Aplikasi dengan Program Lisrel 8.54, Penerbit Undip, Semarang, 2005.

[7] Ghozali, Imam, Aplikasi Analisis Multivariate dengan program SPSS, Cetakan IV. Badan Penerbit Universitas Diponegoro, Semarang, 2012.

[8] Ghozali, Imam, Model Persamaan Struktural : Konsep dan Aplikasi dengan Program AMOS 16.0, Badan Penerbit Universitas Diponegoro, Semarang, 2011.

[9] Hair, J. F., Black, William C., Babin, Barry J., Anderson, Rolph E., \& Tatham, Ronald L. Multivariate Data Analysis (6th ed). New Jersey, Prentice Hall, 2006.

[10] Hinkle, Dennis E., William Wiersma, Stephen G. Jurs.,Applied Statistics for the Behavioral Sciences, New York : Houghton Mifflin Company, 2003.

[11] Indriantoro, Nur dan Bambang Supomo, Metode Penelitian Bisnis untuk Akuntansi dan Manajemen Edisi Pertama, BPFE, 1999.

[12] Jogiyanto, Analisis dan Desain Sistem Informasi, Andi Yogyakarta, 2005.

[13] Marini, Sarwindah, (2017). Analisis Model Penerimaan Teknologi (Technology Acceptance Model) Aplikasi BPJS Online. Jurnal Edukasi dan Penelitian Informatika (JEPIN), halaman: 16-21.

[14] Nasution, M. Faisal Fariduddin Attar, "Investigating Social Influence on Acceptance of Executive Information Systems: A UTAUT Framework Approach", SAIS 2007 Proceedings. Paper 36, 2007, http://aisel.aisnet.org/sais2007/36 (Diakses 4 Juli 2011).

[15] Prahartiwi, L. I. (2017). Pencarian Frequent Itemset pada Analisis Keranjang Belanja Menggunakan Algoritma FP-Growth, Information System For Educators And Professionals, halaman: 1-10.

[16] Priyanka, S dan Kumar, M.A. (2014). "Astudy on Adoption of E-Reccrukment Using Technology Acceptance Model (TAM) With Reference to Graduating Students in Iniversitiesin Bahrain. International Journal of AdvanceResearch in ComputerScienceandManagement Studies. halaman: 2321-7782

[17] Rahardja, Untung, dan Henderi, SIS: Otomatisasi Pelayanan Akademik Kepada Mahasiswa Studi Kasus di Perguruan Tinggi Raharja, Jurnal CCIT, Perguruan Tinggi Raharja, 2007.

[18] Rawstorne, P., R Jayasuriya, P Caputi, “An Integrative of Information Systems Use in Mandatory Environments", International Conference on Information Systems, Pages : 325- 330, 1998.

[19] Sanjaya, R., Ramdhani, Y., \& Prasetio, R. (2016). Implementasi Algoritma Neural Network untuk Klasifikasi Kualitas Kain Tenun. INFORMATIKA, halaman: 3-10

[20] Santoso, Singgih dan Fandy Tjiptono, Riset Pemasaran: Konsep dan Aplikasi dengan SPSS, Elex Media Komputindo, Jakarta, 2002.

[21] Santoso, Singgih, Structural Equation Modelling: Konsep dan Aplikasi dengan AMOS, Elex Media Komputindo, Jakarta, 2007.

[22] Santoso, Singgih, Structural Equation Modelling (SEM) Konsep dan Aplikasi dengan AMOS 18, ElexMedia Komputindo, Jakarta, 2011.

[23] Sayekti, Fran, Putarta. (2016). Penerapan Metode Technology Acceptance Model (TAM) Dalam Pengujian Model Penerimaan Sistem Informasi Keuangan Daerah. Jurnal Manajemen dan Terapan, halaman: 196-209 
[24] Sedana, I Gusti Nyoman dan St. Wisnu Wijaya,"UTAUT Model for Understanding Learning Management System", Internetworking Indonesia Journal Vol.2/No.2, Universitas Sanata Dharma, Yogayakarta, 2010.

[25] Singguh, Santoso, Structural Equation Modeling (SEM) Konsep dan Aplikasi dengan AMOS 18, Jakarta : Elex Media Komputindo, 2011.

[26] Sujarweni, V. Wiratna. (2014). Metode Penelitian. Yogyakarta: Pustaka Baru Press

[27] Sugiyono. (2014). Metode Penelitian Kuantitatif Kualitatif dan R\&D. Bandung: Alfabeta. 